\title{
Improving Yield in Alfalfa Seed Stands with Balanced Fertilization
}

\author{
S. S. Malhi ${ }^{1}$, D. W. Goerzen ${ }^{2}$, C. D. Myhre ${ }^{1}$ and D. Leach ${ }^{1}$ \\ ${ }^{1}$ Agriculture \& Agri-Food Canada, P.O. Box 1240, Melfort, Saskatchewan S0E 1A0 \\ Phone: (306) 752-2776 Ext. 230; Fax: (306) 752-4911; Email: malhis@agr.gc.ca \\ ${ }^{2}$ SASPDC, 127E - 116 Research Drive, Saskatoon, Saskatchewan S7N 3R3
}

\section{Background}

- In western Canada, there are about 70,000 ha grown for alfalfa seed at a value (including leaf-cutter bees) of approximately $\$ 60$ million.

- In north-eastern Saskatchewan, alfalfa is an important forage crop grown for seed.

- About after 3 years, alfalfa can not maintain its original productivity, resulting in low seed yields in some fields (or in areas of the field).

- Weed infestation/competition results in substantial loss in seed yield and hay, and contamination of seed (economic loss in cleaning, lowers the certified seed grade and reduces the marketability of the seed).

- The low production could also be due to depletion of soil fertility, because alfalfa has high requirements for $\mathrm{P}, \mathrm{S}, \mathrm{K}$ and some micronutrients (such as $\mathrm{B}$ ).

- Because of low seed yield and infestation of weeds, alfalfa seed fields are terminated, predominantly by tillage.

- Termination of stands by tillage increases the cost of production due to tillage, reseeding, and can result in substantial $\mathrm{N}$ loss and soil erosion.

- If one nutrient is deficient in soil, crop growth will be poor even if other nutrients are abundant, and this can affect the longevity of alfalfa stands (even if little effect on seed yield).

- Phosphorus improves root development. Sulphur is essential nutrient for N-fixing bacteria, and it affects both yield and quality of seed in legumes. Legumes have higher $\mathrm{S}$ requirements than grasses.

- Potassium stimulates fixation of $\mathrm{N}$ and decreases incidence of winter injury by increasing accumulation of carbohydrates in roots of legumes.

- In north-eastern Saskatchewan, many soils are deficient in S and P, and some sandy soils contain insufficient amounts of $\mathrm{K}$ for high crop yields.

- Most soils are adequately supplied with micronutrients and their deficiencies are rare. Boron deficiency is suspected on sandy soils low in organic matter.

- Under poor fertility, alfalfa can not compete with weeds. Improved soil fertility can make alfalfa out compete weeds, increase longevity of stands by several years and reduce reseeding frequency, and this will also reduce operational costs of production, prevent soil erosion and $\mathrm{N}$ losses, and increase productivity and quality of alfalfa. 


\section{Objective}

To determine the influence of balanced fertilization on seed yield and longevity of alfalfa stands in north-eastern Saskatchewan (remember that nutrient requirements of alfalfa grown for hay are greater than alfalfa seed stands).

\section{Materials and Methods}

- Field experiments were initiated in 2000 on established alfalfa stands.

- Treatments included no fertilizer plus various combinations of fertilizers P, K and S or B at different sites (depending on the nutrient deficiency in soil).

- Fertilizers were surface-broadcast in mid to late April (early spring) on the same plots of every year from 2000 to 2007.

- For this area, mean annual precipitation is $425 \mathrm{~mm}$, and growing season (May to August) precipitation is $244 \mathrm{~mm}$. Precipitation from May to August in 2000, 2001, 2002, 2003, 2004, 2005, 2006 and 2007, respectively, was 247, 175, 110, 56, 295, 330, 208 and 309 $\mathrm{mm}$ at Star City (alfalfa hay/seed experiment), and 274, 185, 275, 87, 418, 395, 264 and $301 \mathrm{~mm}$ at Porcupine Plan (alfalfa seed experiment).

- Alfalfa at maturity was harvested for seed yield in October or November in every year. In a few experiments, alfalfa dry matter yield (DMY) was also taken twice: Cut 1 in late June-Early July and Cut 2 in late August-Early September.

- In addition, field survey trials were conducted to find reasons for poor alfalfa seed yields in various parts of the same farm fields or in adjoining farm fields.

- This included sq m sampling of "Good" and "Bad" areas for seed yield and available nutrients in soil and/or any subsoil problem.

\section{Summary and Conclusions}

- Results of field experiments in different years (with the exception of years with drought and/or early autumn frost) indicated that there was generally an increase in alfalfa seed and/or DMY from fertilization in some fields when soil had low levels of available nutrients. However, in 2006 and 2007 at Star City, seed yields tended to decrease while forage yields increased with many fertilizer treatments. There is no real explanation, but this could be due to additional/excessive growth of alfalfa, resulting in lodging and subsequently poor pollination for seed production in the fertilized treatments.

- Results of survey trials suggest that in some alfalfa seed fields, poor seed yields may be due to nutrient deficiencies and/or a soil fertility imbalance.

- If a soil is testing low (or deficient) in a nutrient and alfalfa growth is reduced, then it is suggested that alfalfa seed producers should plan to use fertilizer to apply an adequate amount of that nutrient lacking in the soil.

- However, even after conducting soil and plant tissue analyses, it is still difficult to predict accurately if a profitable alfalfa seed yield response to fertilization will occur, particularly when the soils are testing marginal in some nutrient levels. 
- Therefore, if it is suspected that a nutrient is deficient in soil, that nutrient should be applied to a portion of the affected area of the field in marked test strip. Visual observations, along with measurements of yield from treated and untreated areas, should be undertaken to determine if a measurable yield response had occurred.

- In order to save money and optimize the use of fertilizers, alfalfa seed producers can use the following suggestions: Apply fertilizers in test strips to find out if there is any increase in alfalfa seed yield and only then consider fertilization of the whole field on a regular basis. If there is a plan in place to use fertilizers on the alfalfa seed field, leave some strips without fertilizers in the field to compare alfalfa seed yields with and without applied fertilizer.

\section{Other Additional Suggestions}

$\checkmark$ Seed yield response to applied fertilizers is affected by:

$\checkmark$ Soil test level of available nutrients in soil (very low/low; marginal).

$\checkmark$ Soil type (texture, organic matter, $\mathrm{pH}$, etc.).

$\checkmark$ Precipitation (total and distribution) and other weather conditions (temperature, frost, etc.)

$\checkmark$ Stand age, population.

$\checkmark$ Fertilizer sources/types, time, method, formulation.

$\checkmark$ Other management factors (residue; seed vs. hay).

\section{Acknowledgements}

The authors thank SASPDC, PPIC and WESTCO for financial assistance; Darwin Leach, Linden McFarlane, K. Strukoff, K. Hemstad-Falk, C. Nielsen and D. Schick for technical assistance; and Erin Cadieu for printing the poster. 
Table 1. Alfalfa seed yields with and without fertilizers at Star City, Saskatchewan.

\begin{tabular}{|c|c|c|c|c|c|c|}
\hline \multirow{2}{*}{ Treatment } & \multicolumn{6}{|c|}{ Seed yield $\left(\mathrm{kg} \mathrm{ha}^{-1}\right)$} \\
\hline & 2000 & 2001 & 2003 & 2004 & 2006 & 2007 \\
\hline No Fert & 359 & 16 & 44 & 39 & 495 & 485 \\
\hline PK & 418 & 80 & 90 & 40 & 443 & 341 \\
\hline KS & 466 & 56 & 52 & 36 & 424 & 441 \\
\hline PS & 406 & 35 & 74 & 38 & 448 & 484 \\
\hline PKS & 424 & 29 & 85 & 29 & 447 & 375 \\
\hline PKSB & 427 & 35 & 77 & 19 & 426 & 372 \\
\hline SEM & $19.9 *$ & $21.6^{\mathrm{ns}}$ & $8.6^{0.10}$ & $7.6^{\mathrm{ns}}$ & $48^{\mathrm{ns}}$ & $48^{\mathrm{ns}}$ \\
\hline
\end{tabular}

Table 2. Alfalfa forage yields with and without fertilizers at Star City, Saskatchewan.

\begin{tabular}{lrrrrrrrr}
\hline \multirow{2}{*}{ Treatment } & \multicolumn{7}{c}{ Forage Yield $\left(\mathrm{kg} \mathrm{ha}^{-1}\right)$} \\
\cline { 2 - 9 } & 2000 & 2001 & 2002 & 2003 & 2004 & 2005 & 2006 & 2007 \\
\hline \multirow{2}{*}{ No Fert } & 5051 & 2112 & 2528 & 1403 & 4304 & 5635 & 8758 & 9164 \\
PK & 4923 & 2486 & 3260 & 1788 & 5394 & 6209 & 8306 & 9313 \\
KS & 5926 & 2942 & 3584 & 1867 & 6354 & 7371 & 9407 & 9377 \\
PS & 5691 & 2050 & 3029 & 1948 & 6618 & 8113 & 9465 & 12369 \\
PKS & 6035 & 2754 & 3098 & 2299 & 7191 & 7907 & 8891 & 12015 \\
PKSB & 6147 & 2435 & 3188 & 2118 & 7067 & 7684 & 9498 & 11612 \\
& & & & & & & & \\
\multicolumn{1}{c}{ SEM } & $217^{* *}$ & $373^{\text {ns }}$ & $330^{\text {ns }}$ & $161^{0.10}$ & $342^{* * *}$ & $369^{* *}$ & $294^{\text {ns }}$ & $592^{* *}$ \\
\hline
\end{tabular}

$\cdot,{ }^{*}, * *, * * *$ and ns refer to significant treatment effects in ANOVA at $\mathrm{P} \leq 0.10, \mathrm{P} \leq 0.05, \mathrm{P} \leq 0.01$, $\mathrm{P} \leq 0.001$ and not significant, respectively.

Table 3. Alfalfa seed yields with and without fertilizers at Porcupine Plain, Saskatchewan.

\begin{tabular}{|c|c|c|c|c|c|}
\hline \multirow{2}{*}{ Treatment } & \multicolumn{5}{|c|}{ Seed yield $\left(\mathrm{kg} \mathrm{ha}^{-1}\right)$} \\
\hline & 2000 & 2001 & 2003 & 2006 & 2007 \\
\hline No Fert & 85 & 167 & 85 & 391 & 218 \\
\hline PK & 76 & 119 & 68 & 517 & 265 \\
\hline KS & 130 & 240 & 140 & 416 & 206 \\
\hline PS & 128 & 263 & 115 & 494 & 290 \\
\hline PKS & 107 & 205 & 122 & 448 & 271 \\
\hline PKSB & 110 & 267 & 107 & 469 & 233 \\
\hline SEM & $14.6^{* * *}$ & $31.8^{* * *}$ & $12.5^{*}$ & $29 *$ & $20^{*}$ \\
\hline
\end{tabular}


Table 4. Alfalfa seed and straw yields with and without fertilizers at Hudson Bay and Valporaiso, Saskatchewan in 2001.

\begin{tabular}{|c|c|c|c|c|}
\hline \multirow{3}{*}{ Treatment } & \multicolumn{4}{|c|}{ Yield $\left(\mathrm{kg} \mathrm{ha}^{-1}\right)$} \\
\hline & \multicolumn{2}{|c|}{ Hudson Bay } & \multicolumn{2}{|c|}{ Valporaiso } \\
\hline & Seed & Straw & Seed & Straw \\
\hline No Fert & 58 & 1310 & 32 & 950 \\
\hline PK & 94 & 1580 & 38 & 850 \\
\hline KS & 85 & 1440 & 25 & 650 \\
\hline PS & 102 & 1770 & 30 & 1020 \\
\hline PKS & 157 & 1800 & 45 & 720 \\
\hline PKSB & 92 & 1950 & 50 & 880 \\
\hline SEM & $67^{\mathrm{ns}}$ & $305^{\mathrm{ns}}$ & $13^{\mathrm{ns}}$ & $132^{\mathrm{ns}}$ \\
\hline
\end{tabular}

ns refers to not significant in ANOVA .

Table 5. Alfalfa seed yields with and without fertilizers at Valparaiso, Mellville and Carrot River Saskatchewan in 2000 and 2001.

\begin{tabular}{|c|c|c|c|c|}
\hline \multirow[b]{2}{*}{ Treatment } & \multicolumn{4}{|c|}{ Seed Yield $\left(\mathrm{kg} \mathrm{ha}^{-1}\right)$} \\
\hline & $\begin{array}{c}\text { Valparaiso } \\
2000\end{array}$ & $\begin{array}{c}\text { Valparaiso } \\
2001\end{array}$ & $\begin{array}{c}\text { Melville } \\
2000\end{array}$ & $\begin{array}{c}\text { Carrot River } \\
2001\end{array}$ \\
\hline & $\underline{\text { No P }}$ & $\underline{\text { No P }}$ & $\underline{\text { No PKS }}$ & $\underline{\text { No } S}$ \\
\hline Unfertilized & 217 & 127 & 340 & 18 \\
\hline & $+\mathrm{P}$ & $+\mathrm{P}$ & $+\mathrm{PKS}$ & $\underline{+S}$ \\
\hline Fertilized & 259 & 175 & 444 & 10 \\
\hline SEM & $28^{\mathrm{ns}}$ & $14 * * *$ & & $6.2^{\mathrm{ns}}$ \\
\hline
\end{tabular}

$* * *$ and $\mathrm{ns}$ refer to significance in ANOVA at $\mathrm{P} \leq 0.001$ and not significant, respectively.

Table 6. Alfalfa seed yields with and without fertilizers at Valparaiso and Carrot River Saskatchewan in 2001.

\begin{tabular}{|c|c|c|}
\hline \multirow{2}{*}{ Treatment } & \multicolumn{2}{|c|}{ Forage Yield $\left(\mathrm{kg} \mathrm{ha}^{-1}\right)$} \\
\hline & Valparaiso & Carrot River \\
\hline & No P fertilizer applied & No S Fertilizer Applied \\
\hline Unfertilized & 1138 & 994 \\
\hline & $\underline{\text { P Fertilizer Applied }}$ & $\underline{\text { S Fertilizer Applied }}$ \\
\hline Fertilized & 1230 & 1870 \\
\hline SEM & $14 * * *$ & $225 * * *$ \\
\hline
\end{tabular}

$* * *$ refers to significance in ANOVA at $\mathrm{P} \leq 0.001$. 
Table 7. Alfalfa seed and straw yields (Bad vs. Good area survey) at various locations in northeastern Saskatchewan (1999 to 2007).

\begin{tabular}{|c|c|c|c|c|c|c|c|c|c|c|c|c|c|c|}
\hline \multirow{5}{*}{$\begin{array}{c}\text { Area } \\
\text { Harvested }\end{array}$} & \multicolumn{14}{|c|}{ Yield $\left(\mathrm{kg} \mathrm{ha}^{-1}\right)$} \\
\hline & \multicolumn{4}{|c|}{ Porcupine Plain } & \multicolumn{6}{|c|}{ Hudson Bay } & \multicolumn{4}{|c|}{ Valporaiso } \\
\hline & \multirow{2}{*}{\multicolumn{2}{|c|}{$\frac{1999}{\text { L. Howse }^{\mathrm{a}}}$}} & \multicolumn{2}{|c|}{2001} & \multirow{2}{*}{\multicolumn{2}{|c|}{$\frac{2000}{\text { D. Nikonetz }}$}} & \multicolumn{2}{|c|}{2001} & \multirow{2}{*}{\multicolumn{2}{|c|}{$\frac{2007}{\text { W. Drebit }^{\mathrm{d}}}$}} & \multirow{2}{*}{\multicolumn{2}{|c|}{$\frac{2000}{P \text { Rov (west) }}$}} & \multicolumn{2}{|c|}{2000} \\
\hline & & & E. H & linaty ${ }^{b}$ & & & D. N & konetz & & & & & P. Roy & $(\text { east })^{f}$ \\
\hline & Seed & Straw & Seed & Straw & Seed & Straw & Seed & Straw & Seed & Straw & Seed & Straw & Seed & Straw \\
\hline $\mathrm{Bad}$ & 60 & 1492 & 101 & 3399 & 41 & 1601 & 15 & 992 & 10 & 326 & 15 & 1010 & 74 & 1419 \\
\hline Good & 201 & 3138 & 660 & 4450 & 387 & 4596 & 555 & 4052 & 489 & 4249 & 201 & 2273 & 136 & 2170 \\
\hline SEM & $20 *$ & $193 * *$ & $35 * * *$ & $126 * * *$ & $15 * * *$ & $191 * * *$ & $27 * * *$ & $109 * * *$ & $42 * *$ & $254 * * *$ & $21 * *$ & $114 * *$ & $5 * * *$ & $124 * *$ \\
\hline
\end{tabular}

$*, * *, * * *$ and $\mathrm{ns}$ refer to siginicant effects in ANOVA at $\mathrm{P} \leq 0.05, \mathrm{P} \leq 0.01, \mathrm{P} \leq 0.001$ and not significant, respectively.

${ }^{\mathrm{a}}$ Soil test $2.4 \mathrm{ppm} \mathrm{P}$ and 8.0 ppm $\mathrm{SO}_{4}-\mathrm{S}$.

${ }^{\mathrm{b}}$ Low P.

${ }^{\mathrm{c}}$ Soil test $3.0 \mathrm{ppm}$ (bad) vs. $11.0 \mathrm{ppm}$ (good) and large O.M. difference between bad and good.

${ }^{\mathrm{d}}$ Soil test still too come.

${ }^{\mathrm{e}}$ Soil test $4.5 \mathrm{ppm} \mathrm{P}$ and $8.0 \mathrm{ppm} \mathrm{SO}_{4}-\mathrm{S}$.

${ }^{f}$ Soil test $5.0 \mathrm{ppm} \mathrm{P}$ and $9.0 \mathrm{ppm} \mathrm{SO}_{4}-\mathrm{S}$. 